\title{
METHYLATION OF E. COLI TRANSFER RIBONUCLEIC ACIDS BY A tRNA ADENINE-1-METHYLTRANSFERASE FROM RAT BRAIN CORTEX AND BULK-ISOLATED NEURONS
}

\author{
Carlos E. Salas ${ }^{1}$ and Otto Z. Sellinger ${ }^{2}$ \\ Laboratory of Neurochemistry, Mental Health Research Institute, University of Michigan Medical Center,
} 205 Washtenaw Place, Ann Arbor, MI 48109, U.S.A.

(Received 17 October 1977. Accepted 2 February 1978)

\begin{abstract}
Brain cortices or bulk-isolated neuronal cell bodies prepared from cortices of 8-day old male rats were used as the source of a 1-methyl adenine-specific tRNA methyltransferase (tRNA-AMT). Ammonium sulfate fractionation and chromatography on spheroidal hydroxylapatite and Sephadex G-200 yielded an 80-fold purified enzyme, as determined by using $E$. coli bulk tRNA as substrate. The kinetic parameters of tRNA-AMT for the substrate $S$-adenosyl-L-methionine (SAM) $\left(K_{m}=6 \mu \mathrm{M}\right)$ and the inhibitor, $S$-adenosyl-L-homocysteine (SAH) $\left(K_{i}=3.4 \mu \mathrm{M}\right)$ were determined and several SAH analogs tested as inhibitors. S-Adenosyl-L-cysteine (SAC) $\left(10^{-4} \mathrm{M}\right)$ and $S$-adenosyl-D-homocysteine (SADH) $\left(10^{-4} \mathrm{M}\right)$ produced a 35 and a $21 \%$ reduction in enzyme activity, respectively. The effects of $\mathrm{Mg}^{2+}, \mathrm{NH}_{4}^{+}$acetate and of the polyamines spermine, putrescine and spermidine on the brain tRNAAMT mimicked the effects of these agents on hepatic tR NA-AMT (GLICK et al., 1975).

Comparing the ability of cerebral tRNA-AMT to methylate $E$. coli tRNA $^{\mathrm{glu}_{2}}, \mathrm{tRNA}^{\mathrm{val}}, \mathrm{tRNA}^{\text {phe }}$ and bulk tRNA revealed tRNA ${ }^{\mathrm{gle}_{2}}$ as the best and $\mathrm{tRNA}{ }^{\text {phe }}$ as the least effective substrate.

IRNA-AMT prepared from neuronal cell bodies showed closely similar characteristics to the cortical enzyme. A comparison of the activities of tRNA-AMT in neurons and glial cells revealed higher values in the former.
\end{abstract}

tRNA adenine 1-methyltransferase [EC 2.1.1.36] (tRNA-AMT) is an enzyme or group of closely related enzymes that methylates the 1 position of adenine residues in a tRNA polynucleotide chain. Unlike the recently reported non-specific RNA adenine-1methyltransferase extracted from the nuclear fraction of the dinoflagellate Cripthecodinium cohnii (WERNER et al., 1976), tRNA-AMT seems to recognize specific sequences within the tRNA molecule for the insertion of the methyl group (KUCHINo \& Nishimura, 1974).

In the past years several attempts have been made to purify this enzyme using biological material from different sources (e.g. rat liver, HeLa cells and prokaryotic cells) (Baguley \& Staehelin, 1968a,b; Kuchino \& Nishimura, 1970; Agris et al., 1974; Kerr, 1974; Glick et al., 1975). The activity was shown to be affected by polyamines, divalent cations, ammonium acetate. SAM and SAH (Young \& SRIN1VASAN, 1971; Pegg, 1971; HaCker, 1973; LeboY \& GiICK, 1976). In a previous study we reported a relative decrease in the methylation of $E$. coli bulk tRNA adenine residues when $2.5 \mathrm{~mm}$-spermidine was present

\footnotetext{
'Present address: Institut de Biologie Moleculaire et Cellulaire du C.N.R.S., Laboratoire de Biochimie, 15 rue Rene Descartes, 67084 Strasbourg, France.

${ }^{2}$ To whom correspondence should be addressed

Abbreviations used: TRNA-AMT, TRNA adenine-1methyltransferase: SAM, $S$-adenosyl-L-methionine; SAH, $S$-adenosyl-L-homocysteine; SAC, S-adenosyl-L-cysteine: SADH, $S$-adenosyl-D-homocysteine;
}

in the incubation mixture containing a crude enzyme preparation from rat brain cortex (SAlAS et al., 1976). At least two possibilities were suggested to explain the observed results: (a) spermidine inhibits the methylation of adenine residues in position 1 ; or (b) the methylation of all other bases is proportionately higher than that of adenine in position 1 , and this is reflected in an apparent, relative decrease in the percentage of 1-methyladenine formed. The same study (SALAS et al., 1976) also showed a relative enrichment in tRNA-AMT activity in extracts derived from bulk-isolated nerve cell bodies (SELLINGER et al., 1971) as compared to similar preparations obtained from the brain cortex (neurons + glial cells). To clarify some of these issues, we decided to examine the cellular localization of IRNA-AMT and compare some of the properties of the partially purified enzyme obtained independently from the cortex and its nerve cell bodies.

\section{EXPERIMENTAL PROCEDURES}

\section{Materials}

S-Adenosyl-L-[methy $\left.]^{-14} \mathrm{C}\right]$ methionine (specific activity $45 \mathrm{mCi} / \mathrm{mmol}$ ) was purchased from Research Products International (Elk Grove Village, IL); E. coli bulk tRNA from Schwartz-Mann (Orangeburg, NY); $E$. coli tRNA ${ }^{\text {phe }}$ and $E$. coli RNA $^{\text {val }}$ from Miles Laboratories (Elkhart, IN); $E$. coli $\mathrm{RNNA}^{\mathrm{qlu}}$ and $S$-adenosyl-i-methionine from Boehringer Mannheim (Indianapolis, IN). The methylated 
bases used as standards were from Sigma Chemical Company (St. Louis. MO): $\mu$ Bondapak $C_{18}$ columns $(30 \times 0.4$ I.D. $\mathrm{cm}$ f from Waters Associates, Inc. (Milford, MA); trifluoroacetic acid from Matheson, Coleman and Bell (East Rutherford. $\mathrm{NJ}$ ); ammonium phosphate monobasic from J. J. Baker (Phillipsburg. NJ); spheroidal hydroxylapatite from Gallard-Schlesinger (Carle Place, NY); $S$-adenosyl-Lhomocysteine and its analogs from Sefochem Fine Chemicals (Jordan Valley. Israel). Spermidine phosphate was from Sigma Chemical Co. (St. Louis, MO), putrescine dihydrochloride and spermine tetrahydrochloride were from Mann Research Laboratories (New York, NY).

\section{Apparatus}

A solvent delivery system equipped with a dual piston pump, model $6000 \mathrm{~A}$. a universal liquid chromatography injector model U6K and an absorbance detector model 440 were from Waters Associates, Inc. (Milford, MA). The chromatographic run was recorded on an Omniscribe recorder, Texas Instruments (Austin. TX).

\section{Methods}

Hydrolysis of [methy $\left.i^{-14} \mathrm{C}\right] t R N A$. Trifluoroacetic acid $(1 \mathrm{ml})$ was added to [methyl $\left.{ }^{-14} \mathrm{C}\right] \mathrm{tRNA}$ in a combustion tube $(25 \times 2.01 . \mathrm{D} . \mathrm{cm})($ A. H. Thomas Co., Philadelphia, PA) sealed under vacuum and incubated at $170^{\circ} \mathrm{C}$ for $30 \mathrm{~min}$. After hydrolysis the trifluoroacetic acid was evaporated under a stream of $\mathrm{N}_{2}$ at room temperature and the dry residue stored at $4^{\circ} \mathrm{C}$

Chromatographic analysis. The tRNA hydrolysate (SALAS et al. 1976) containing between 2000 and $10,000 \mathrm{dpm}$ was dissolved in water $(0.2 \mathrm{ml})$ and applied to the column via the injector septum at room temperature using a $100 \mu \mathrm{l}$ syringe (Precision Sampling Corp., Baton Rouge, LA). After sample injection the flow rate was maintained at $2 \mathrm{ml} / \mathrm{min}$. For optimal separation (Salas \& Sellinger. 1977) of the [methyl ${ }^{-14} \mathrm{C}$ ] bases in the hydrolysate, buffer solutions were changed $350 \mathrm{~s}$ after injection. Fractions $(0.02-0.1 \mathrm{ml})$ were collected in plastic mini-vials (Rochester Scientific Co., Inc., Rochester, NY) to which $2 \mathrm{ml}$ of tissue solubilizer-scintillation mixture was added (Amersham, Searle, Arlington Heights, IL). The radioactivity of the samples was determined in a Beckman 250 liquid scintillation spectrometer. All buffers and samples were filtered through Millipore filters $(0.45 \mu \mathrm{m}$ pore size) and were degassed in vacuo prior to use.

Methylation of E. coli $t R N A$ in vitro. Both the 'rate' and 'extent' methylation assay mixtures (PEGG, 1971) as applied to brain tissue have been described elsewhere (SAlas et al., 1976). For the study of the kinetic parameters and of the effects of SAH analogs on enzyme activity the assays were performed in the 'rate' mode.

Preparation of $\operatorname{RNA} A-A M T$. Male, Sprague-Dawley rats ( 8 days-old) were decapitated and the brain cortices (approx $15 \mathrm{~g}$ ) quickly removed and homogenized in a glass-Teflon Potter-Elvehjem homogenizer to a final volume of 3.5 times the tissue weight. The buffer solution contained $10 \mathrm{~mm}$-Tris- $\mathrm{HCl} \mathrm{pH} \quad 7.6,1 \mathrm{~mm}$-EDTA and $1 \mathrm{~mm}$-dithiothreitol (DTT). The homogenate was centrifuged at $165,000 \mathrm{~g}$ for $150 \mathrm{~min}$ and the clear supernatant fractionated with a saturated solution of ammonium sulfate at pH 7.0 (PEGG, 1971). The final pellet was recovered by centrifugation, resuspended in $10 \mathrm{~mm}$-Tris- $\mathrm{HCl}$ buffer pH 8.0 , containing $1 \mathrm{~mm}$-EDTA and $1 \mathrm{~mm}$-DTT (buffer A) and was dialyzed overnight against 31 of the same buffer.
The dialysis residue (ca. $10 \mathrm{ml}$ ) was then made $1 \mathrm{~mm}$ in Na phosphate and applied to a column $(25 \times 1.5 \mathrm{~cm})$ of spheroidal hydroxylapatite, previously equilibrated with the same buffer. The column was then washed with a volume of buffer, equivalent to that of the sample, following which a linear gradient of $\mathrm{Na}$ phosphate $(1-400 \mathrm{~mm}$; $300 \mathrm{ml}$ ) in buffer $A$ was used to elute the enzyme. The total tRNA methyltransferase activity in the eluates was determined using $E$. coli bulk IRNA as methyl acceptor Peak I (Fig. 1A) was pooled and concentrated by precipitation with solid ammonium sulfate to $80 \%$ saturation. The precipitate was collected by centrifugation and dissolved in $2.0 \mathrm{ml}$ of $50 \mathrm{~mm}$-Tris, $\mathrm{pH} 8.0$ containing $0.1 \mathrm{~mm}$-EDTA and $1 \mathrm{~mm}$-DTT and was dialyzed overnight against 21 of the same buffer. The non-diffusible material was applied to a column $(130 \times 0.9 \mathrm{~cm})$ of Sephadex G-200 previously equilibrated with the $50 \mathrm{~mm}$-Tris buffer. Enzyme activity was eluted using the same Tris buffer and fractions were pooled and concentrated by solid ammonium sulfate precipitation $(80 \%)$. The precipitate obtained after centrifugation was dissolved in a small volume of buffer $\mathrm{A}$. Measured aliquots of the enzyme were stored at $-70^{\circ} \mathrm{C}$.

IRNA-AMT from neuronal cell bodies. Neuronal cell bodies, prepared from cerebral cortices of 8 day-old male rats as previously described (SELLINGER et al., 1971; SELLINGER \& AZCURRA, 1974) were suspended and homogenized in the same buffer used for whole cortices $(3.5 \mathrm{ml} / \mathrm{g}$
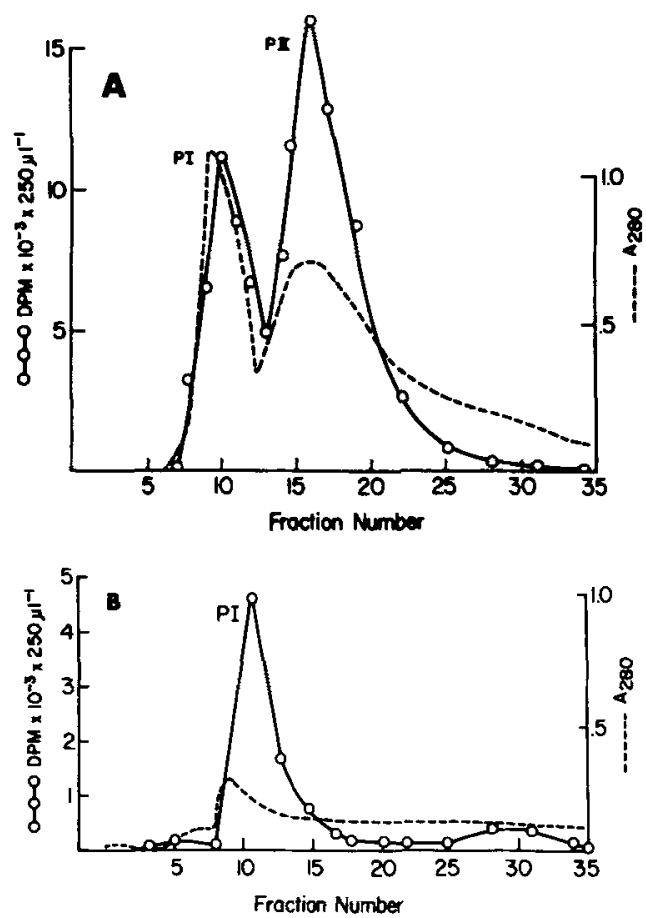

Fig. 1. Spheroidal hydroxylapatite chromatography of rat brain IRNA methyltransferases. The column was eluted with a linear $1-400 \mathrm{~mm}-\mathrm{Na}$ phosphate gradient. Aliquots $(250 \mu \mathrm{l})$ were analyzed for $\mathrm{IRNA}$ methyltransferase activity in the 'rate' mode (PEGG, 1971). (A) whole brain cortex tRNA methyltransferases. (B) neuronal tRNA methyltransferases. For details see Methods. 


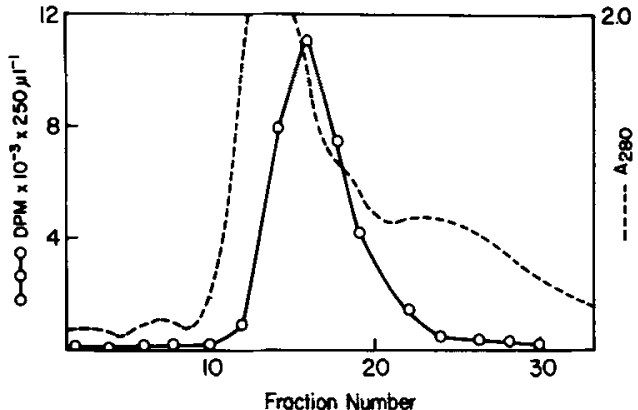

FIG. 2. Chromatography of tRNA-AMT from whole rat brain cortex on Sephadex G-200. Aliquots $(250 \mu \mathrm{l})$ were tested for tRNA-AMT activity in the 'rate' mode. For details, see Methods.

of neuronal pellet). Subsequent treatment of this preparation was identical to that described for the cortical enzyme.

Protein determination. Protein was determined according to LowRy et al. (1951), using crystalline bovine serum albumin as standard.

\section{RESULTS}

Spheroidal hydroxylapatite chromatography resolved two peaks of methyltransferase activity, as shown in Fig. 1A. The first peak contained most of the tRNA-AMT, while the second peak contained some tRNA-AMT + significant tRNA-guanine $\mathrm{N}^{2}$. methyltransferase and tRNA-guanine- $N_{2}^{2}$-dimethyltransferase activity. In contrast, equivalent preparations derived from cortical neuronal cell bodies contained virtually only tRNA-AMT enzyme activity, as shown in Fig. 1B. It should be noted that the elution volumes for the first peak in Figs. $1 \mathrm{~A}$ and $1 \mathrm{~B}$ were the same regardless of the source of the enzyme. Also, the ammonium sulfate precipitation and dialysis steps prior to chromatography were found to be essential for the successful separation of IRNA-AMT from the other tRNA-methylating activities.

Peak 1 (Fig. 1A) was further purified by passage through a column of Sephadex G-200 (Fig. 2). The effluent fractions containing tRNA-AMT activity were treated as described in Methods and were stored at $-70^{\circ} \mathrm{C}$ for up to 6 months without detectable loss of activity.

To determine the methyl base specificity of tRNAAMT unequivocally, bulk $E$. coli tRNA was methylated using enzyme preparations partially purified through the hydroxylapatite and/or Sephadex G-200 steps. The resulting [methyl $\left.{ }^{-14} \mathrm{C}\right] \mathrm{tRNA}$ was hyrolyzed with trifluoroacetic acid at $170^{\circ} \mathrm{C}$ for $30 \mathrm{~min}$ and following the evaporation of the acid, the hydrolyzates were subjected to high performance liquid chromatography (HPLC) as described in Methods (Salas \& Sellinger, 1977). The radiometric analysis of the HPLC eluates revealed that virtually all of the radioactivity was confined to the elution position corresponding to 1-methyladenine (Fig. 3). Separate methylation assays using cortical enzyme preparations revealed, in addition to $\left[\right.$ methyl $\left.{ }^{-14} \mathrm{C}\right] 1$ methyladenine, residual amounts of $\left[\right.$ methyl $\left.{ }^{-14} \mathrm{C}\right] \mathrm{l}$ methylguanine and $\mathrm{N}^{2}$-methylguanine, both representing no more than $10 \%$ of the total $\left[\right.$ methyl ${ }^{-14} \mathrm{C}$ ]tRNA formed. Table 1 summarizes the purification procedure of tRNA-AMT from whole brain cortex.

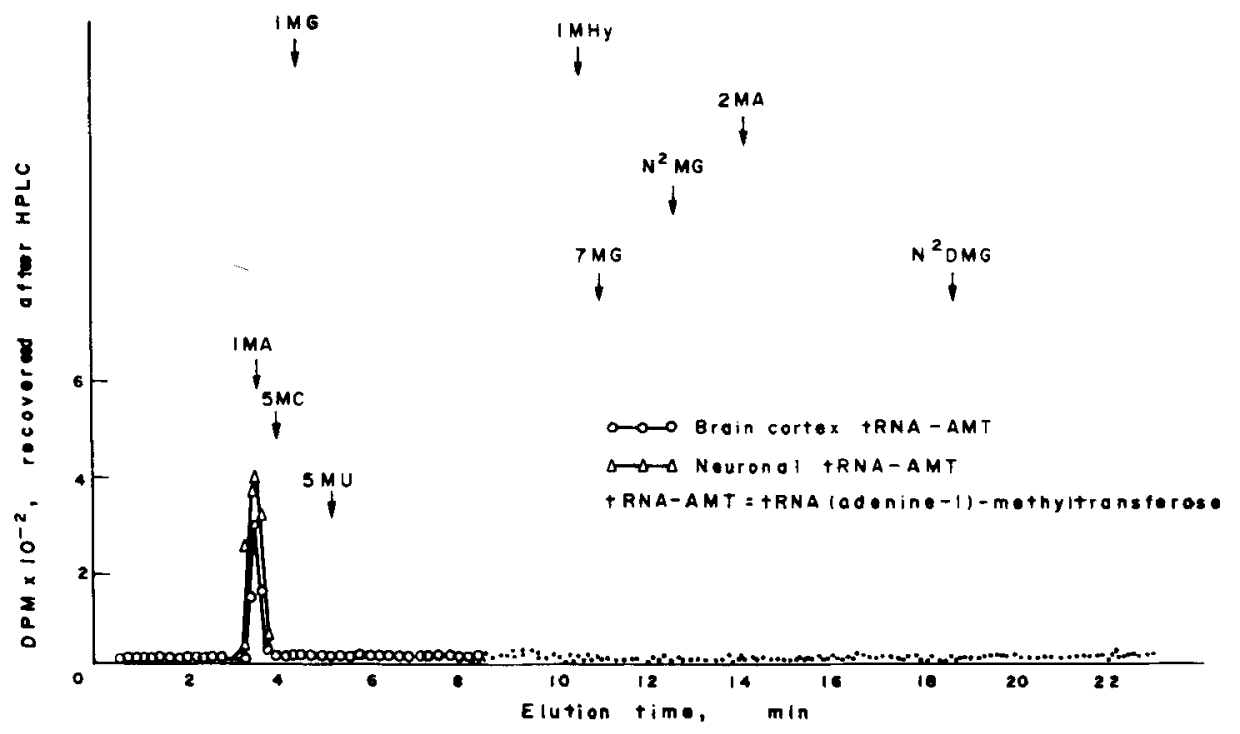

Fig. 3. High performance liquid chromatography (HPLC) of $E$. coli $\left[\right.$ methyl ${ }^{-14}$ ] $R$ RA hydrolvzates on $\mu$ Bondapak $C_{1}$. The enzyme activity was measured in the 'extent' mode (PEGG, 1971). For details. see Methods. 
Table 1. Purification of tRNA-AMT from rat brain CORTEX*

\begin{tabular}{|c|c|c|c|c|c|c|c|}
\hline Fraction & $\begin{array}{l}\text { Vol. } \\
(\mathrm{ml})\end{array}$ & Unitst/ml & Total units & $\begin{array}{l}\text { Protein } \\
(\mathrm{mg} / \mathrm{ml})\end{array}$ & $\begin{array}{l}\text { Units/mg } \\
\text { protein }\end{array}$ & $\begin{array}{l}\text { Yield } \\
(\%)\end{array}$ & $x$-fold \\
\hline Homogenate & 52 & 61,534 & $3.2 \times 10^{6}$ & 19.8 & 528 & 100 & 0 \\
\hline $\begin{array}{l}\text { High speed } \\
\text { supernatant }\end{array}$ & 48 & 41,665 & $2.0 \times 10^{6}$ & 6.7 & 1057 & 62.5 & 2.0 \\
\hline $\begin{array}{l}\text { Ammonium } \\
\text { sulfate ppt. } \\
\text { Hydroxylapatite } \\
\text { Sephadex G-200 }\end{array}$ & $\begin{array}{r}13 \\
3 \\
3\end{array}$ & $\begin{array}{r}99,995 \\
137,852 \\
11,360\end{array}$ & $\begin{array}{l}1.3 \times 10^{6} \\
4.1 \times 10^{5} \\
5.7 \times 10^{4}\end{array}$ & $\begin{array}{c}15.2 \\
11.3 \\
0.27\end{array}$ & $\begin{array}{r}1118 \\
12,200 \\
42,074\end{array}$ & $\begin{array}{r}40.6 \\
12.9 \\
1.8\end{array}$ & $\begin{array}{r}2.1 \\
23.1 \\
79.7\end{array}$ \\
\hline
\end{tabular}

Comparing the effects of $\mathrm{NH}_{4}^{+}$and $\mathrm{Mg}^{2+}$ revealed a range of concentrations over which the activity of both the cortical and neuronal IRNA-AMT failed to change much. The range was 3-7 $\mathrm{mm}$ for $\mathrm{Mg}^{2+}$ and $0.2-0.8 \mathrm{M}$ for $\mathrm{NH}_{4}^{+}$. Using $100 \mathrm{~mm}$-Tris buffer, maximal tRNA-AMT activity was found between pH 8.2-8.4.

The findings shown below are from experiments in which we used IRNA-AMT from whole brain cortex (unless otherwise stated); the enzyme derived from nerve cell bodies yielded analogous results. Figure 4 is a comparative study of the effect of different concentrations of spermidine, spermine and putrescine on whole cortex tRNA-AMT. Spermidine produced a maximal stimulatory effect at $2-3 \mathrm{mM}$, as previously demonstrated for the unfractionated brain cortex tRNA methyltransferases (SALAS et al., 1976). Alternatively, 1-mm-spermine and 40-60 mM-putrescine were the most suitable concentrations to produce maximal tRNA-AMT activity. In another experiment the kinetic parameters for tRNA-AMT were examined and an apparent $K_{m}$ of $6 \mu \mathrm{M}$ determined for SAM. The methylation of tRNA was competitively inhibited by SAH with a $K_{i}$ of $3.4 \mu \mathrm{M}$.

Table 2 lists the effect of a number of $\mathrm{SAH}$ analogs on the activity of the neuronal tRNA-AMT. Of all compounds tested, the strongest inhibitory effect was produced by $\left(10^{-4} \mathrm{M}\right) S$-adenosyl-L-cysteine (SAC) $(35 \%)$, while a weaker effect was observed with $\left(10^{-4} \mathrm{M}\right) \mathrm{S}$-adenosyl-D-homocysteine (SADH) $(21 \%$ ).

A further characterization of tRNA-AMT was undertaken using individual $E$. coli tRNA species as substrates. As shown in Table 3, the extent methylation of the various $E$. coli tRNAs varied markedly, that of $\mathrm{TRNA}^{\mathrm{s} \mathrm{u}_{2}}$ being the most and that of $\mathrm{RNA}^{\mathrm{phc}}$ being the least effective. The extent methylations of $t R N A^{\text {phe }}$ and tRNA ${ }^{\text {val }}$ were equivalent to $12 \%$ and $20 \%$ respectively, of that noted with tRNA ${ }^{\text {glu }}$, in good agreement with similar values obtained using rat liver tRNAAMT (KuChino \& Nishimura, 1974; Glick et al., 1975).

To determine the cellular distribution of tRNAAMT, fractions of equivalent purity were prepared from whole cerebral cortex, bulk-isolated neuronal cell bodies and glial cells (SELLINGER et al., 1971) and cultured astrocytes derived by growing 3-day old whole rat brain cortex in primary culture for 12-14 days (CUMmins \& GLOVER, in press). Table 4 shows that [methyl ${ }^{-14} \mathrm{C}$ ]1-methyladenine represented $41.5 \%$ of the total radioactivity recovered after HPLC in the neurons as against $30.2 \%$ and $28.1 \%$ in the two types of glial cells, with an intermediate $32.1 \%$ in the whole cortex. Conversely $N^{2}$-methylguanine formation (SALAS et al., 1977) was significantly higher in both

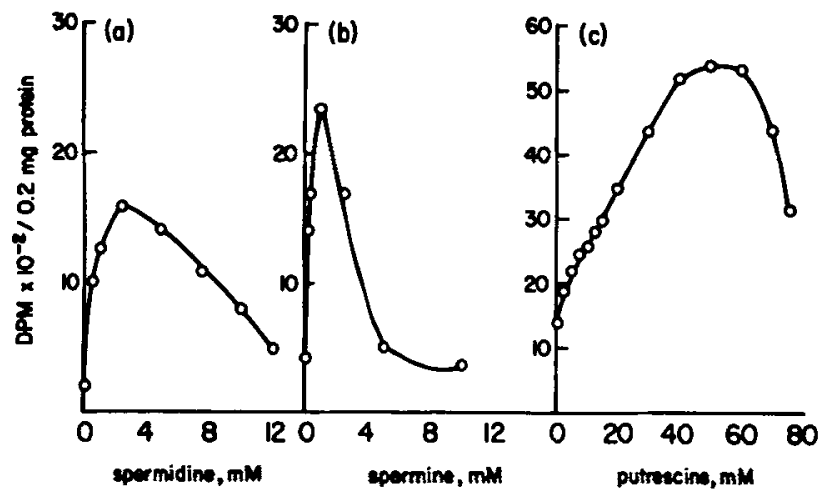

FIG. 4. Effect of polyamines on tRNA-AMT activity using bulk E. coli tRNA. The enzyme activity was measured in the 'rate' mode using cortical tRNA-AMT. 
TABLE 2. THE INHIBITION OF BRAIN tRNA-AMT

\begin{tabular}{lccc}
\hline \multicolumn{1}{c}{ Compound } & \multicolumn{2}{c}{$\begin{array}{c}\text { \% Inhibition } \\
10^{-5} \mathbf{M}\end{array}$} & $10^{-6} \mathbf{M}$ \\
\hline S-Adenosyl-L-homocysteine & $10^{-4} \mathbf{M}$ & 34 & 2.2 \\
S-Adenosyl-D-homocysteine & 84 & 12 & 2.2 \\
S-Adenosyl-L-cysteine & 21 & 0 & 0 \\
S-5'-Butyl-5'-deoxyadenosine & 35 & 0 & 0 \\
S-Adenosyl-5'-deoxy-5'-thioethanol & 0 & 0 & 0 \\
S-5'-1sobutyl-5'-deoxyadenosine & 0 & 0 & 0 \\
2- $O$-Methyladenosine & 0 & 0 & 0 \\
9- $\beta$-D-Arabinofuranosyladenosine & 0 & 0 & 0 \\
9- $\beta$-D-Arabinofuranosylhypoxanthine & 0 & 0 & 0 \\
1- $\beta$-D-Arabinofuranosyluracil & 0 & 0 & 0 \\
Adenosine & 0 & 0 & 0 \\
\hline
\end{tabular}

Neuronal cells from 8-day old rat cerebral cortex were used as the source of the enzyme. tRNA-AMT was incubated in the presence of $E$. coli tRNA, 2.5 mM-spermidine and $S$-adenosyl-L-[methyl ${ }^{-14} \mathrm{C}$ ] methionine for $30 \mathrm{~min}$ at $37^{\circ} \mathrm{C}$, followed by $10 \%$ cold TCA precipitation. Radioactivity was recovered on Millipore filters (see Methods).

bulk-isolated $(42.2 \%)$ and cultured $(34.1 \%)$ glial cells than in the neuronal cell bodies $(18.2 \%)$.

\section{DISCUSSION}

A procedure is described which yields an 80 -fold purified tRNA-AMT, essentially free of contaminating guanine-specific tRNA methyltransferases, from the 8-day old rat cerebral cortex and its neurons. The procedure requires relatively small amounts of tissue (ca. $15 \mathrm{~g}$ ). It is of interest that a much higher degree of purification and hence a much more laborious procedure was found necessary to free tRNA-AMT of rat liver (GLICK et al., 1975) and of HeLa cells (AGRIS et al., 1974) of contaminating tRNA methyltransferases. No differences were detected in the present study between the tRNA-AMT purified from the whole cortex and that purified from its neuronal cell bodies (Figs. 1-3).
Table 3. Methylation of individual $\boldsymbol{E}$. coli TRNA SPECIES

\begin{tabular}{lc}
\hline tRNA & Relative activity \\
\hline Bulk & 1.00 \\
tRNA & 0.71 \\
tRNA $^{\text {phe }}$ & 0.43 \\
tRNA $^{\text {Blu }}$ & 3.57 \\
\hline
\end{tabular}

Enzymes were from 8-day old rat cerebral cortex. 'Extent' assay was performed in the presence of $2.5 \mathrm{~mm}$-spermidine, $1 \mathrm{mg}$ of brain protein and tRNA between 1.5 and $20 \mathrm{nmol}$. Incubation: $2 \mathrm{~h}$.

*Activity with bulk tRNA: $6.3 \times 10^{4}$ d.p.m./mg/120 min.

The study of tRNA-AMT inhibitors (Table 2) demonstrated that $10^{-4} \mathrm{M}$-SAH inhibited tRNA-AMT almost totally while $10^{-6} \mathrm{M}$-SAH failed to inhibit the enzyme. Inhibition by $10^{-4} \mathrm{M}-\mathrm{SADH}$ and $\mathrm{SAC}$ was

TABLE 4. A COMPARISON OF TRNA METHYLTRANSFERASE METHYLATING CAPACITY IN CEREBRAL CORTEX, BULK-ISOLATED CORTICAL NEURONS AND GLIAL CELLS AND CULTURED ASTROCYTES*

\begin{tabular}{lcccc}
\hline & \multicolumn{3}{c}{ Bulk-isolated $\dagger$} \\
[Methyl $\left.{ }^{-14} \mathrm{C}\right]$ Base & Whole cortex & $\begin{array}{c}\text { Neuronal } \\
\text { perikarya }\end{array}$ & $\begin{array}{c}\text { Glial } \\
\text { cells }\end{array}$ & $\begin{array}{c}\text { Cultured } \\
\text { astrocytes } \ddagger\end{array}$ \\
\hline l-Methyladenine & 32.1 & 41.5 & 30.2 & 28.1 \\
5-Methylcytosine & 16.8 & 13.7 & 9.6 & 16.7 \\
l-Methylguanine & 2.4 & 9.0 & $\mathrm{~N} . \mathrm{D}$. & 10.0 \\
l-Methylhypoxanthine & 7.7 & 5.7 & 8.2 & 7.4 \\
$N^{2}$-Methylguanine & 28.4 & 18.2 & 42.2 & 34.1 \\
$N_{2}^{2}$-Dimethylguanine & 9.5 & 9.9 & 9.8 & trace \\
Minor bases & 3.1 & 2.0 & $\mathrm{~N} . \mathrm{D}$. & 3.7 \\
Total radioactivity \pm (d.p.m.) & 11.143 & 12.713 & 1476 & 9848 \\
\hline
\end{tabular}

* Values are expressed as $\%$ of total recovered radioactivity after HPLC set to $100 \%$. The actual recovery of d.p.m. among the methylated bases as \% of the d.p.m. injected into the HPLC machine was above $90 \%$ in most cases and approached $95 \%$ in some. tRNA methyltransferases: ammonium sulfate precipitate $(0-80 \%)$ of the $165,000 \mathrm{~g} / 150 \mathrm{~min}$ supernatant obtained from the homogenate of the indicated tissue or cell source. N.D. Not detected

+ By the procedure of Sellinger et al. (1971): \$ By the procedure of Cummins \& Glover (1978).

'Extent' assay, $2 \mathrm{~h}$. Spermidine: $2.5 \mathrm{~mm}$ : Substrate: $E$. coli tRNA (bulk). $10 \mu \mathrm{g}$. 
$35^{\circ}$ and $21^{\circ}$ orespectively, indicating a lower effectiveness of these analogs, when compared to SAH (HILDESHEIM et al., 1973a, b; TREWYN \& KeRR, 1976). Comparing the inhibitions by SAC and SADH revealed that the length of the amino acid chain is not a critical factor determining their efficacy as tRNA-AMT inhibitors and that $10^{-5} \mathrm{M}-\mathrm{SADH}$ is slightly more effective than $10^{-5} \mathrm{M}-\mathrm{SAC}$.

The concentration of $\mathrm{NH}_{4}^{+}$necessary for maximal stimulation of brain tRNA-AMT was higher than that (0.1-0.25 M) previously reported for both non-neural (Pegg, 1971; Young \& SRinivasan, 1971; Hancock \& Eleftheriou, 1971) and neural (Hancock \& EleFTHERIOU, 1971) tRNA methyltransferases and, more recently, by LEBOY \& GLICK (1976) for the highly purified rat liver tRNA-AMT. The rat brain tRNAAMT also appeared to differ from the purified rat liver enzyme (LEBOY \& GLICK, 1976) in terms of its $\mathrm{Mg}^{2+}$ requirements, since appreciable activity was determined in the presence of $2-10 \mathrm{mM}-\mathrm{Mg}^{2+}$ with no polyamines or $\mathrm{NH}_{4}^{+}$co-present, whereas LEBOY \& GLICK (1976) reported negligible activity in the presence of $0.5-10 \mathrm{mM}-\mathrm{Mg}^{2+}$, when compared to the activity measurable in the presence of optimal $\mathrm{NH}_{4}^{+}$ concentrations. Alternatively, comparing the total d.p.m. incorporated into tRNA (Figs. 4A-C), reveals that putrescine (Fig. 4C) produced the maximal stimulatory effect.

The in vitro stimulation of IRNA methyltransferases by spermine, spermidine and putrescine (Fig. 5) is a well documented phenomenon (PEGG, 1971; Young \& SRINIVASAN, 1971; Hacker, 1973; LeboY \& Piester, 1973; Cummins et al., 1975; Salas et al., 1976, 1977; DAINAT et al. 1977). It is of interest to note, however, that while spermine affected brain tRNA-AMT and non-neural tRNA methyltransferases optimally at approx 1-1.5 mM (PEGG, 1971; Young \& SRINIVASAN, 1971; HaCker et al., 1973), spermidine and putrescine affected brain tRNA-AMT and non-neural tRNA methyltransferases differently. For example, Pegg (1971) found maximal stimulation of rat liver tRNA methyltransferases by $15-25 \mathrm{~mm}-$ putrescine, while brain tRNA-AMT (Fig. 4) required 40-60 mm-putrescine for optimal activity, a value which compared favorably with the values of $60 \mathrm{mM}$ and $40-50 \mathrm{~mm}$ found optimal for the tRNA methyltransferases of leukemic cells (HACKER, 1973) and purified rat liver tRNA-AMT (LFBOY \& GLICK, 1976). Our results also show (Fig. 4) that, like the rat liver tRNA methyltransferases (PEGG, 1971; YouNG \& SRINIVASAN, 1971), brain IRNA-AMT required 2-3 mM-spermidine, whereas the purified liver tRNAAMT (LebOY \& GLICK, 1976) was maximally stimulated by $12-14 \mathrm{~mm}$-spermidine. It is of further interest that HACKER (1973) noted two spermidine concentration optima for the tRNA methyltransferases of the leukemic cells, one at 3 and the other at approx $10 \mathrm{~mm}$. Although the ranking of the polyamines' effectiveness as stimulators of cerebral tRNA-AMT agrees with the accepted notion that putrescine is the most effective polyamine (HACKER, 1973), MOLLER et al. (1977) recently showed $10 \mathrm{~mm}$-spermine to be most effective in stimulating tRNA methylation by adult rat brain extracts and $20 \mathrm{~mm}$-spermidine to be most effective with the fetal and the newborn rat brain enzymes.

When TRNA-AMT was tested with different individual $E$. coli tRNA species (Table 3), tRNA ${ }^{\text {gluz }}$ and tRNA $^{\text {phe }}$ proved to be the best and the least effective substrates, respectively. These results are in complete accord with the findings of KuCHINO \& NishimurA (1974) and of Guick et al. (1975) who used adult rat liver TRNA-AMT. Examining the methylation of tRNA $^{\text {fmet }}$ by tRNA methyltransferases of the immature (6 days) and weanling ( 21 days) rat cerebellum (DAINAT et al., 1977, and unpublished observations) we recently noted that in the 6-day old animal I-methyl-adenine formation failed to exceed $10 \%$ of the total methylated bases formed, while at 21 days it rose to approx $38 \%$ in the absence of spermidine, being virtually nil in its presence. These findings suggest a finely tuned and developmentally controlled sensitivity of this reaction toward polyamines.

The results shown in Table 4 demonstrate that neurons contain appreciable levels of tRNA-AMT activity, in confirmation of our previous circumstantial findings (SAlas et al,, 1976). To find out whether IRNA-AMT is selectively enriched in neurons, we prepared TRNA-AMT-containing fractions from bulkisolated and cultured glial cells and compared them to equivalent cortical and neuronal fractions. The results indicate that, although both glial preparations contained tRNA-AMT activity, the per cent contribution of [methyl $\left.{ }^{-14} \mathrm{C}\right] 1$-methyladenine to the total methylated bases was significantly lower in the glial cells than in the whole cortex or the neurons. On the premise that the content in IRNA-AMT of each isolated cell type reflects the in vivo situation, neurons are therefore a relatively richer source of IRNA-AMT than are glial cells. Whether the neuronal and the glial IRNA-AMT activities have different site specificities, as do the enzymes of Phaseolus vulgaris (DUBoIs et al., 1974), and whether the enrichment of tRNAAMT in nerve cells has a functional correlate, i.e. the control of the synthesis of neuron-specific proteins remains to be established.

\section{REFERENCES}

Agris P. F., Spremulli L. L. \& Brown G. M. (1974) Archs Biochem. Biophys. 162, 38-47.

Baguley B. C. \& StaEhelin M. (1968a) Biochemistry 7, 45-50

Baguley B. C. \& Staehelin M. (1968b) Eur. J. Biochem. 6, 1-7.

Cummins C. J. \& Glover R. A. J. Anat., Lond. in press. Cummins C. J., Salas C. E. \& Sellinger O. Z. (1975) Brain Res. 96, 407-412.

Dainat J., Salas C. E. \& Sellinger O. Z. (1977) Trans. Am. Soc. Neurochem. 8, 228. 
Dubois E. G., Dirheimer G. \& WeIl J. H. (1974) Biochim. biophys. Acta 374, 332-341.

Guick J. M., Ross S. \& LeboY P. S. (1975) Nucl. Acids Res. 2, 1639-1652.

HACKER B. (1973) Polyamines in Normal and Neoplastic Growth, pp. 55-69. Raven Press, New York.

Hacker B., Hurwitz C., McDermott B. J. \& Rosano C. L. (1973) Physiol. Chem. Phys. 5, 491-501.

Hancock R. L. \& Eleftheriou B. E. (1971) Physiol. Chem Phys. 3, 139-148.

Hildesheim J., Gogulloon J. \& Lederer E. (t973a) FEBS Lett. 30, 177-180.

Hildesheim J., Hildesheim R., Blanchard P., Farrugia G. \& Michelot R. (1973b) Biochimie 55, 541-546.

KERR S. J. (1974) Meth. Enzymol. 29, 716-726.

Kuchino Y. \& Nishimura S. (1970) Biochem. biophys. Res. Commun. 40, 306-313.

Kuchino Y. \& Nishimura S. (1974) Biochemistry 13, 3683-3688.

Leboy P. S. \& GuICK J. M. (1976) Biochim biophys. Acta 435, 30-38.

Leboy P. S. \& Piester P. (1973) Polyamines in Normal and Malignant Growth, pp. 103-110. Raven Press, New York.
Lowry O. H., Rosebrough N. J., FarR A. L. \& Randall R. J. (1951) J. biol. Chem. 1933, 265-275.

Moller M. L., Miller H. K. \& Balis M. E. (1977) Biochim. biophys. Acta 474, 425-434.

PEGG A. E. (1971) Biochim. biophys. Acta 232, 630-642.

Salas C. E. Sellinger O. Z. (1977) J. Chromat. 133, 231-236.

Salas C. E., Cummins C. J. \& Sellinger O. Z. (1976) Neurochem. Res. 1, 369-384.

Salas C. E., Ohlsson W. G. \& Sellinger O. Z. (1977) Biochem. Biophys. Res. Commun. 76, 1107-1115.

Seluinger O. Z. \& Azcurra J. M. (1974) Research Methods in Neurochemistry, Vol. 2, pp. 3-38. Plenum Press, New York.

Sellinger O. Z., Azcurra J. M., Johnson D. E., Ohlsson W. G. \& Lodin Z. (1971) Nature, New Biol. 235, 253-256.

TREWYN R. W. \& KeRR S. J. (1976) Onco-Developmental Gene Expression, pp. 101-106. Academic Press, New York.

Werner E., Kahle P., Lange U. \& Kroger H. (1975) FEBS Lett. 55, 245-248.

Young D. V. \& SRINIVASan P. R. (1971) Biochim. biophys. Acta 238, 447-463. 